\title{
The Successful Use of Vitamin D in Physical Urticaria
}

\section{Veronica A Varney ${ }^{1 *}$ and Amena Warner ${ }^{2}$}

${ }^{1}$ Respiratory Department, St. Helier Hospital, Wrythe Lane, Carshalton, Surrey, SM5 1AA, UK

${ }^{2}$ Allergy Clinic Immunology Department, St. Helier Hospital, Wrythe Lane, Carshalton, Surrey, SM5 1AA, UK

\begin{abstract}
Physical urticarias are disorders of the skin occurring in response to a number of physical stimuli (pressure temperature and ultra violet light). The condition is characterized by painful swelling and burning at the site of the stimulus. High dose anti-histamines combined with montelukast seldom control the condition completely. The exact cause of the skin pathology is not fully understood and this has limited new treatment options. We describe a case series in which significant daily symptoms of physical urticaria were occurring without an adequate response to treatments other than steroids. The patients were asked to commence an oral Vitamin D3 supplement in view of its widespread anti-inflammatory effects on the immune system. In all cases symptoms resolved within 2-4 months allowing regular medication to stop. We discuss briefly the possible actions of Vitamin D3 on the immune system in this case series.
\end{abstract}

Keywords: DPU urticaria; Physical Urticaria; Solar urticaria; Vita$\min \mathrm{D}$

Abbreviations: DPU: Delayed Pressure Urticaria; SU: Solar Urticaria; IL-6: Interleukin-6; LT: Leukotriene; HDM: House Dust Mite; IgE: Immunoglobulin E; CU: Chronic Urticaria

\section{Introduction}

Physical urticaria is a heterogeneous group of diseases with differing stimuli of which pressure, temperature and ultra-violet light are well described [1]. Atopy and chronic urticaria are frequently associated with the condition [2]. Acute and chronic urticaria generally responds well to antihistamines but this is not the case for physical urticaria, where response is usually unsatisfactory [3]. As a result combination treatments have been used and many of these are described in the literature. They include antihistamine combinations with other drugs such as montelukast, ketotifen, NSAIDS and dapsone [4,5]. Oral steroids are very effective but long-term treatment is limited by adverse effects. For intractable cases, treatment with anti-IgE infusions and infusions of intravenous immunoglobulin appear successful, but are expensive, time consuming and unlikely to be generally available $[6,7]$.

The physical urticarias appear to be associated with a different pathology to acute and chronic urticaria where mast cell histamine release is predominant. Studies in Delayed Pressure Urticaria (DPU) and Solar Urticaria (SU) suggest dermal inflammation with inflammatory cells (neutrophils, eosinophils and basophils) and a late phase-like reaction. Interleukin-6 is raised in lesional skin along with raised eosinophil-derived major basic protein and leukotrienes $\mathrm{B} 4, \mathrm{C} 4$, D4 and E4 suggesting non-mast cell dependant mechanisms [8-11]. The exact pathogenesis is still a puzzle and this influences the development of effective treatment especially for severe cases. We describe 5 cases of physical urticaria in which oral Vitamin D supplements were given with resolution of symptoms over a few months. The sites of action of Vitamin D on the immune system and inflammation are multiple and we discuss its possible actions in these patients.

\section{Case}

\section{Case 1}

Gave a history of acute urticaria to penicillin and eggs from the age of 11 years, which she subsequently avoided (Table 1). As an adult, she would develop acute urticaria with every virus requiring steroids to settle the giant urticaria. In addition she had severe symptoms (previously diagnosed by a dermatologist) of both pressure and cold temperature induced urticaria for 14 years which had significantly reduced her life quality. DPU occurred severely on her legs and buttocks on sitting with burning pain. After her spinning classes she would develop forearm, wrist and hand swellings along with buttock swelling that would be very uncomfortable until it resolved. With cold weather or cold exposure she would develop giant urticaria. Her symptoms had never been controlled by antihistamines and montelukast, hence her frequent steroid courses. She had deteriorated further in the last 2-3 years and was referred to the allergy clinic. We explained to her our observation in the allergy clinic of a significant benefit from Vitamin D3 in physical urticaria. She commenced $3000 \mathrm{IU} /$ day from the health shop which was increased to $5000 \mathrm{IU} /$ day in view of her very low blood level of $25 \mathrm{OH}$ Vitamin D (Table 1). All other bloods were normal including inflammatory markers, thyroid, complement, immunoglobulin's and auto-antibodies.

At 2 months review her DPU symptoms had settled and review was planned for mid-winter when she suffered the addition of cold temperature induced urticaria and giant urticaria with virus infection requiring prednisolone. At winter review all her symptoms had settled and she had stopped all medication (antihistamines and antileukotrienes) except for Vitamin D. After her spinning classes she developed no DPU symptoms and even a recent severe virus had passed uneventfully. Her cold temperature induced urticaria had gone and she described herself as normal. She was advised to continue 1000$2000 \mathrm{IU} /$ day long-term. On discharge she commented that she had suffered this condition for years and couldn't believe that the cure came from a Vitamin! This comment prompted us to collect together our

*Corresponding author: Veronica A Varney, Respiratory Department, St. Helier Hospital, Wrythe Lane, Carshalton, Surrey, SM5 1AA, UK, Tel: 004402082962401 Fax: 004402082963163; E-mail: veronica. varney@esth. nhs. uk

Received October 15, 2014; Accepted November 27, 2014; Published December 01,2014

Citation: Varney VA, Warner A (2014) The Successful Use of Vitamin D in Physical Urticaria. J Allergy Ther 5: 200. doi:10.4172/2155-6121.1000200

Copyright: (c) 2014 Varney VA, et al. This is an open-access article distributed under the terms of the Creative Commons Attribution License, which permits unrestricted use, distribution, and reproduction in any medium, provided the original author and source are credited. 
most recently remembered cases for publication, as we have found this treatment so effective in our allergy clinic.

\section{Case 2}

Gave a history of irritable bowel syndrome with loose stools, abdominal pain and bloating which was the main focus of her referral to the allergy clinic (Table 1). Skin testing confirmed tree, grass and wheat allergy and wheat avoidance settled the abdominal symptoms completely at her first review. At that review she then enquired about her long history of DPU which was affecting her life quality especially now the bowel symptoms had resolved. She reported that this symptom had not changed on the wheat free diet. It occurred on her shoulders and arms if carrying bags and on her buttocks and legs on sitting for long periods. She had to avoid crossing her legs due to DPU of her knees and tight shoes would cause it to develop on her feet. She had taken cetirizine $30 \mathrm{mg}$ and montelukast $10 \mathrm{mg}$ long term without any benefit to the DPU, but found it useful for her seasonal rhinitis. We asked her to commence Vitamin D 2000 IU/day for the DPU and on review at 4 months, she reported that her DPU was only fleetingly noticed as one mild episode a month compared with daily before. As a result of the improvement she had stopped the montelukast and taken cetirizine only as required for rhinitis. We recommended that she continue 1000-2000 IU/day long term.

\section{Case 3}

Described a lifetime history of asthma with atopic rhinitis, and allergy to house dust mite. In the past two courses of house dust mite desensitization for her asthma and rhinitis had occurred (1948 and 1974) and she was referred due to deterioration of her asthma and rhinitis (Table 1). On attendance she informed us of her need for high dose anti-histamines due to severe solar urticaria. She had to avoid all sunlight and reported that to even drive her car wearing total sunblock cream and leather gloves she would still develop painful urticaria through the gloves if the sun shone on the steering wheel from spring until Autumn. She was under the guidance of a leading hospital photodermatology clinic that had established that she had solar urticaria to UVA (380-400 $\mathrm{nm}$ wavelength) with an immediate erythema and a papular response (even though gloves) at 30 minutes that resolved after 2-3 hrs. The antihistamines and total sunblock to reduce exposure was not working. The reaction had started approximately 2 years before and the patient wondered whether a course of oral doxycycline was the trigger initially. We suggested she started some oral Vitamin D 3 due to our observations of improvement with physical urticaria and she

\begin{tabular}{|c|c|c|c|c|c|}
\hline Cases & 1 & 2 & 3 & 4 & 5 \\
\hline Diagnosis & $\begin{array}{l}\text { DPU } \\
\text { Cold urticaria }\end{array}$ & DPU & SU & DPU & $\begin{array}{l}\text { DPU } \\
\text { Cold urticaria }\end{array}$ \\
\hline Duration & $\begin{array}{l}\text { 14yrs } \\
\text { Worse from } 2011\end{array}$ & Years worse $>2 y r s$ & $1-2$ yrs & $10 y r s$ & $1 \mathrm{yr}$ \\
\hline Age(sex) & $44(f)$ & $63(f)$ & $71(F)$ & $47(F)$ & $19(F)$ \\
\hline Ethic Group & Caucasian & Caucasian & Caucasian & Afrocarribean & Caucasian \\
\hline Atopic & $\begin{array}{l}\text { Yes } \\
\text { HDM }\end{array}$ & $\begin{array}{l}\text { Yes } \\
\text { Airborne } \\
\text { Wheat }\end{array}$ & $\begin{array}{l}\text { Yes } \\
\text { HDM } \\
\text { Sulphite reactions }\end{array}$ & $\begin{array}{l}\text { Yes } \\
\text { Grass, tree, HDM, nuts, banana, } \\
\text { yeast }\end{array}$ & $\begin{array}{l}\text { Yes } \\
\text { Wheat } \\
\text { banana }\end{array}$ \\
\hline Other conditions & Nil & $\begin{array}{l}\text { Irritable bowel syndrone } \\
\text { Hypertension } \\
\text { Lichen planus }\end{array}$ & $\begin{array}{l}\text { Past immunotherapy } 1948 \\
\text { and } 1974\end{array}$ & $\begin{array}{l}\text { Hypertension } \\
\text { Seasonal asthma } \\
\text { Steroid-induced psychosis }\end{array}$ & Eczema \\
\hline Chronic urticaria & no & no & yes & yes & no \\
\hline $\begin{array}{l}\text { Acute } \\
\text { urticaria }\end{array}$ & $\begin{array}{l}\text { Viruses } \\
\text { Eggs } \\
\text { penicillin }\end{array}$ & $\begin{array}{l}\text { Aspirin } \\
\text { Grass pollen }\end{array}$ & Solar UVA (380-400 nm) & Grass pollen & banana \\
\hline $\begin{array}{l}\text { Previous } \\
\text { treatment }\end{array}$ & $\begin{array}{l}\text { Steroids } \\
\text { Cetirizine } \\
\text { Loratidine } \\
\text { montelukast }\end{array}$ & $\begin{array}{l}\text { Cetirizine } \\
\text { Montelukast } \\
\text { Steroids } \\
\text { Candesartan } \\
\text { Moduretic } \\
\text { Omeprazole } \\
\text { nifedipine }\end{array}$ & $\begin{array}{l}\text { Cetirizine/ fexofenadine } \\
\text { Total UV block creams }\end{array}$ & $\begin{array}{l}\text { Prednisolone } \\
\text { Ranitidine } \\
\text { Montelukast } \\
\text { Phenergan } \\
\text { Chlorpheniramine } \\
\text { Eurax cream } \\
\text { Assorted H2 } \\
\text { Antihistamines } \\
\text { Cetirizine, loratidine }\end{array}$ & $\begin{array}{l}\text { Loratidine } \\
\text { Prednisolone } \\
\text { montelukast }\end{array}$ \\
\hline $\begin{array}{l}\text { Routine and immune blood } \\
\text { tests }+\end{array}$ & normal & Normal & $\begin{array}{l}\text { Normal } \\
\uparrow ~ I g E ~ H D M\end{array}$ & $\begin{array}{l}\text { Normal } \\
\uparrow \text { IgE grass }\end{array}$ & normal \\
\hline $\begin{array}{l}25 \mathrm{OH} \text { Vitamin } \\
\mathrm{D} \text { at referral } \mathrm{nmol} / \mathrm{I}^{*}\end{array}$ & 30 & 44 & 48 & 43 & Not measured \\
\hline $\begin{array}{l}\text { Vitamin D dose } \\
\text { commenced }\end{array}$ & 5000 IU/day & 2000 IU/day & 2000 IU/day & 4000 IU/day & 2000 IU/day \\
\hline Time to improvement & 2 months & 4 months & 3 months & 4 months & 2 months \\
\hline Outcome & $\begin{array}{l}\text { Resolved to } \\
\text { DPU, cold and viral } \\
\text { illness }\end{array}$ & $\begin{array}{l}\text { DPU } \\
\text { Resolved } \\
\text { Vitamin D }\end{array}$ & $\begin{array}{l}\text { SU Resolved } \\
\text { All drugs and creams stopped } \\
\text { No clothing } \\
\text { Protection needed }\end{array}$ & $\begin{array}{l}\text { Resolved } \\
\text { All drugs stopped }\end{array}$ & $\begin{array}{l}\text { Remaining mild DPU } \\
\text { on fingers only }\end{array}$ \\
\hline Follow-up/relapses & $\begin{array}{l}2 \text { and } 6 \text { month. } \\
\text { none }\end{array}$ & $\begin{array}{l}2 \mathrm{yr} \\
\text { Resolved as long as she } \\
\text { stays on vitamin D }\end{array}$ & $\begin{array}{l}4 \text { yrs } \\
\text { Resolved and holiday in } \\
\text { California gave no problems }\end{array}$ & 3 yrs & $\begin{array}{l}3 \text { years and stable } \\
\text { without symptoms }\end{array}$ \\
\hline
\end{tabular}

* $<20 \mathrm{nmol} / \mathrm{l}$ : severe deficiency $\quad 20-50 \mathrm{nmol} / \mathrm{l}$ : insufficiency $\quad 50-200 \mathrm{nmol} / \mathrm{l}$ : replete

+ blood count, liver and kidney function, thyroid, protein and calcium levels, C-reactive protein, complement and auto-antibodies,ANCA,C3,C4,C1assay and function

Table 1: Case Summary. 


\begin{tabular}{|c|c|c|c|}
\hline Cell & Action & Mechanism & References \\
\hline Macrophages/monocyte & $\begin{array}{l}\text { Promotes differentiation } \\
\text { Inhibit dendritic cell differentiation } \\
\text { Reduced inflammatory Cytokines } \\
\text { Reduces co-stimulatory molecules }\end{array}$ & $\begin{array}{l}\uparrow 1 \text { 1a hydroxylase } \\
\uparrow 1 \text { a hydroxylase } \\
\downarrow \text { IL-6,8,12, TNF* } \\
\downarrow \text { CD40, CD80, CD86 and HLA-DR* }\end{array}$ & {$[13,14,18-20]$} \\
\hline T cells & $\begin{array}{l}\text { Homing to inflamed tissue } \\
\text { Homing to skin } \\
\text { Increased T regulatory cells } \\
\text { Reduced inflammatory cytokines }\end{array}$ & $\begin{array}{l}\text { †CCR5, CXCR3, CXCR6* } \\
\uparrow \mathrm{CCR} 10 \\
\uparrow \mathrm{IL}-10, \text { TLR-9*} \\
\downarrow \text { IL-17, IL-2, IFN-gamma }\end{array}$ & {$[13,14,16,18,20]$} \\
\hline Dendritic cells & $\begin{array}{l}\text { Increased T cell regulation } \\
\text { Reduced immune response } \\
\text { Reduced co-stimulatory molecules } \\
\text { Reduced cytokine release }\end{array}$ & $\begin{array}{l}\uparrow \text { IL-10, TGFß } \\
\downarrow \text { IL-17 } \\
\downarrow \text { CD1a, CD14, CD40, CD86 } \\
\downarrow \text { IL-12, IL-23 }\end{array}$ & {$[12,13,14,18,20]$} \\
\hline Mast cells & $\begin{array}{l}\text { Stabilise mast cell } \\
\text { Reduces IgE dependant pro-inflammatory mediators }\end{array}$ & $\begin{array}{l}\downarrow \text { histamine release } \\
\uparrow \text { IL-10 }\end{array}$ & {$[18,21,23]$} \\
\hline
\end{tabular}

${ }^{*}$ CCR and CXC-chemokine receptors IL-interleukin TLR-toll-like receptors, TGFß-transforming growth factor-beta, TNF-tissue necrosis factor. HLA: Human Leukocyte Antigens. IFN--gamma-interferon-gamma. CD-cluster designation of immune system cells

Table 2: Effects of 1,25 hydroxy-vitamin D on immune cells that may effect physical Urticaria [22,23].

was assessed and commenced on sublingual HDM desensitization. On follow-up for her immunotherapy at 3 months, she reported that she was not developing SU and she slowly progressed to not wearing gloves and stopped sunscreen by 6 months and subsequently anti-histamines. No relapse of her SU nor her asthma/ rhinitis occurred. The HDM immunotherapy improved her rhinitis and asthma. She was delighted with these events; we did not feel that the sublingual immunotherapy was responsible for the improvement in the SU, although both had been commenced together. She continued oral Vitamin D long-term and reports that she visit California as a holiday without solar Urticaria.

\section{Case 4}

Referred due to multiple allergies, associated with severe chronic urticaria, DPU and cold urticaria that was extremely difficult to control (Table 1). She had known hayfever and asthma in the grass season with acute on chronic urticaria at that time resulting in significant angioedema which would take many months to settle after the grass pollen season. She denied chronic asthma or eczema. Pressure and ice testing was strongly positive. Skin testing confirmed she was atopic to airborne allergens, nuts, yeasts and banana. With oral prednisolone above $20 \mathrm{mg} /$ day she had developed severe steroid psychosis in the past when used by the dermatologists. This dose had been required due to the severity of the Chronic Urticaria (CU) with daily DPU which had not responded to other drugs. She suffered high blood pressure and in the allergy clinic we discontinued her aspirin and changed her Angiotensin Receptor Inhibitor (ACEI) to a calcium channel blockers in order to reduce any possible aggravation by these drugs. This gave some improvement to her chronic urticaria. Her prednisolone remained at 5-10 $\mathrm{mg}$ without which her symptoms were intolerable. Every anti-histamine was tried in increasing doses and in combination with ranitidine, montelukast and phenergan along with antihistamine creams and topical eurax cream. Little progress was made and frequent review in the allergy clinic was required over 7-8 years. In the grass season acute angioedema would require increased steroids, due to the increased severity of her daily DPU causing great distress. At this time we had not observed the benefit of Vitamin D in any patient.

We decided upon some sublingual grass pollen immunotherapy to see if settling the seasonal aggravation of her CU and DPU could facilitate a reduction in steroids use. Improvement by $40-50 \%$ in her summer hay fever and acute urticaria did occur. This did little for her DPU and cold urticaria. We suggested in 2011 she took some Vitamin D $800 \mathrm{IU} /$ day when we were first observing a benefit in other patients. No apparent benefit was observed in her in the first year. After another admission for severe DPU to her feet, hands, legs and buttocks she admitted that she had never followed our advice of taking Vitamin D. We then suggested that she took high dose Vitamin D (4000 IU/d) as her Vitamin D levels were low and she was clinically a severe case. Within 2 months the DPU had dramatically reduced along with the Cold urticaria. Steroid reduction was begun at $1 \mathrm{mg}$ every $4-6$ weeks. No relapses occurred during weaning and cessation and all symptoms resolved. In the following grass pollen season minimal eye and nasal symptoms occurred and the allergy problems were settled. She was advised to stay on 1000-2000 IU/day long term.

\section{Case 5}

Referred to the allergy clinic due to 37 attacks of pressure induced swelling (Table 1). This affected her fingers, arms, back, feet, lips and tongue. Swelling would occur rapidly after a hot or chilled drink or if ice-lolly or ice cream was licked or put into her mouth. She had small patches of eczema over her buttocks but tests showed no sensitivity to gluten. She was strongly positive on the pressure and ice testing developing immediate positive ice test and significant DPU at $2 \mathrm{hrs}$ after the test. SPT showed her to be highly atopic to airborne allergens with large reaction to wheat and banana and smaller reactions to rye, tomato and cashew nut. She gave no history of irritable bowel syndrome. On oral challenge off her anti-histamines she confirmed that bananas caused rapid lip swelling independent of the temperature induced symptoms. We advised her to commence oral Vitamin D in view of her physical urticaria and on review at 2 months, all lip, tongue and mouth swelling had ceased and she was now able to drink hot and chilled drinks and ice cream etc. The bulk of her DPU had resolved from her arms, back and feet. She described milder swelling of her fingers on carrying very heavy shopping only. Avoiding wheat products had cleared her eczema patches Progress was maintained at 4 month review and she was advised to stay on Vitamin D at 1000-2000 $\mathrm{IU} /$ day and discharged from the clinic.

\section{Discussion}

Urticaria and allergic conditions are increasing and Vitamin D3 deficiency (25 hydroxy-Vitamin D) is now recognized as a global issue with effects on health including dysregulation of the immune system [12]. The understanding of its effects on the immune system has grown dramatically in the last decade and some of the recognized effects are summarized in Table 2.

1,25 hydroxy-Vitamin D receptors are present on mast cells, macrophages, $\mathrm{T}$ and $\mathrm{B}$ lymphocytes and other antigen presenting and 
dendritic cells where the main effect is to reduce inflammation and increase $\mathrm{T}$ cell regulatory function [13]. The immune system generates 1,25 hydroxy-Vitamin D from serum 25 hydroxy-Vitamin D [14]. The latter reliably reflects Vitamin D status of the individual. 1,25 hydroxyVitamin D is important for glucocorticoid receptor functioning with widespread anti-inflammatory effects [15]. Micro-array work shows that within the $\mathrm{CD} 4 \mathrm{~T}$-cell alone, 102 genes are targeted with 57 downregulated and 45 up-regulated [16] by 1,25 hydroxy Vitamin D. Within the skin, the presence of inflammation and inflammatory cytokines increases the local production of 1, 25 hydroxy-Vitamin D usually by macrophages which can then reduce the production of inflammatory cytokines (Interleukin-6,8,12,17,23 and tissue necrosis factor- $\alpha$ ) $[13,17]$. This reduces the infiltration of neutrophils, eosinophils and basophils [13,18]. When 25 hydroxy-Vitamin D levels are $<50 \mathrm{nmol} / \mathrm{l}$, human monocytes and macrophages are unable to initiate some innate immune responses [19]. In mast cells, 1, 25 hydroxy-Vitamin $\mathrm{D}$ activates mast cell Interleukin-10 production without degranulation which suppresses mast cell derived pro-inflammatory mediators invitro $[18,20]$. This would reduce the generation of leukotriene C4 which generates D4 and E4 and activation of eosinophils as observed in the dermal inflammation described in the physical urticarias [21]. T-cell "homing" to skin sites of inflammation via the CC-chemokine receptor-10 is increased by 1,25 hydroxy-Vitamin $\mathrm{D}$, where it can attenuate antigen presentation by skin dendritic cells and increase T-cell regulation of inappropriate Th- 1 and Th- 2 responses. This could potentially suppress late phase-like reactions observed in physical urticaria [22-24]. In our case series 4 out of 5 patients who measured their serum 25 hydroxy-Vitamin D levels were deficient with values between $30-48 \mathrm{nmol} / \mathrm{l}$. These levels are below that required for bone health $(75 \mathrm{nmol} / \mathrm{l})$, although much debate does exist around minimal and optimal levels of 25 hydroxy-Vitamin D [25]. A National study of Vitamin D levels in British adults in various UK regions (south, middle, north, Scotland) showed an average $21 \%$ variation between winter and summer values with lowest levels in the North. For the south of England mean adult blood 25 hydroxy-Vitamin D levels were $42.6 \mathrm{nmol} / \mathrm{l}$ in winter and $62.4 \mathrm{nmol} / \mathrm{l}$ in summer [26]. This would have the closest correlation with our patients in Surrey who were all indoor workers. Our supplementation with Vitamin D was designed to elevate their blood levels to values $>100 \mathrm{nmol} / \mathrm{l}$, since it is thought that optimal immune health requires higher blood levels of Vitamin D3 than those required for bone health [12,17]. For subjects with a Vitamin D receptor polymorphism that affects Vitamin D "effector" function, elevation of Vitamin D levels in the blood appears to minimize the defect and is the subject of much research currently [27].

In our case series, the slow responses (2-4 months) of the physical urticaria to oral Vitamin D could reflect slow re-adjustment of the immune system with down-regulation of on skin inflammation. The cessation of all prior treatments for the condition upon improvement suggests an independent and sustained anti-inflammatory effect on the skin independent of the drugs. Skin biopsies in physical urticaria comparing changes before and after Vitamin D treatment and its effect on cellular infiltration in the skin would be interesting. In situ hybridization could also be used to assess changes in cytokine expression and may give further understanding of this condition.

\section{References}

1. Dice JP (2004) Physical urticaria. Immunol Allergy Clin North Am 24: 225-246.

2. Barlow RJ, Warburton F, Watson K, Black AK, Greaves MW (1993) Diagnosis and incidence of delayed pressure urticaria in patients with chronic urticaria. $J$ Am Acad Dermatol 29: 954-958.
3. Kontou-fili K, Maniatako G, Demakos P, Gonianakis M, Palaiologos G (1991) Therapeutic effects of cetirizine in delayed pressure urticaria; clinico-pathologic Finding. J Am Acad Dermatol 24: 1090-1093.

4. Nettis E, Colanardi MC, Soccio AL, Ferrannini A, Vacca A (2006) Desloratadine in combination with montelukast suppress the dermographometer challenge test papule, and is effective in the treatment of delayed pressure urticaria: a randomised, double-blind, placebo-controlled study. Brit J Derm 155: 12791282.

5. Berkun $Y$, Shalit M (2000) Successful treatment of delayed pressure urticaria with montelukast. Allergy 55: 203-204.

6. Güzelbey O, Ardelean E, Magerl M, Zuberbier T, Maurer M, et al. (2008) Successful treatment of solar urticaria with anti-immunoglobulin $E$ therapy. Allergy 63: 1563-1565.

7. Dawn G, Urcelay M, Ah-Weng A, O'Neill SM, Douglas WS (2003) Effect of highdose intravenous immunoglobulin in delayed pressure urticaria. $\mathrm{Br} \mathrm{J}$ Dermato 149: $836-840$

8. Lawlor F, Black AK (2004) Delayed pressure urticaria. Immunol Allergy Clin North Am 24: 247-258, vi-vii.

9. Grabbe J (2001) Pathomechanisms in physical urticaria. J Investig Dermatol Symp Proc 6: 135-136.

10. Cassano N, Mastrandrea V, Vestita M, Vena GA (2009) An overview of delayed pressure urticaria with special emphasis on pathogenesis and treatment Dermatol Ther 22 Suppl 1: S22-26.

11. Kobza-Black A (2001) Delayed pressure urticaria. J Investig Dermatol Symp Proc 6: 148-149.

12. Schwalfenberg GK (2011) A review of the critical role of vitamin D in the functioning of the immune system and the clinical implications of vitamin $D$ deficiency. Mol Nutr Food Res 55: 96-108.

13. Maruotti N, Cantatore FP (2010) Vitamin D and the immune system. J Rheumatol 37: 491-495.

14. Guillot X, Semerano L, Saidenberg-Kermanac'h N, Falgarone G, Boissier MC (2010) Vitamin D and inflammation. Joint Bone Spine 77: 552-557.

15. Norman AW, Mizwicki MT, Norman DP (2004) Steroid-hormone rapid actions, membrane receptors and a conformational ensemble model. Nat Rev Drug Discov 3: 27-41.

16. Mahon BD, Wittke A, Weaver V, Cantorna MT (2003) The targets of vitamin $\mathrm{D}$ depend on the differentiation and activation status of CD4 positive T cells. $J$ Cell Biochem 89: 922-932.

17. Aranow C (2011) Vitamin D and the immune system. J Investig Med 59: 881 886

18. Hewison $M(2010)$ Vitamin $D$ and the immune system: new perspectives on an old theme. Endocrinol Metab Clin North Am 39: 365-379.

19. Fabri M, Stenger S, Shin DM, Yuk JM, Liu PT, et al. (2011) Vitamin D is required for IFN-gamma-mediated antimicrobial activity of human macrophages. Sc Transl Med 3: 104ra102.

20. Agrawal T, Gupta GK, Agrawal DK (2013) Vitamin D supplementation reduces airway hyperresponsiveness and allergic airway inflammation in a murine model. Clin Exp Allergy 43: 672-683.

21. Reinholz M, Ruzicka T, Schauber J (2012) Vitamin D and its role in allergic disease. Clin Exp Allergy 42: 817-826.

22. Hart PH, Gorman S, Finlay-Jones JJ (2011) Modulation of the immune system by UV radiation: more than just the effects of vitamin D? Nat Rev Immunol 11: 584-596.

23. Harvima IT, Nilsson G (2011) Mast cells as regulators of skin inflammation and immunity. Acta Derm Venereol 91: 644-650.

24. Gupta A, Dimeloe S, Richards DF, Chambers ES, Black C, et al. (2014) Defective IL-10 expression and in vitro steroid-induced IL-17A in paediatric severe therapy-resistant asthma. Thorax 69: 508-515.

25. Priemel M, von Domarus C, Klatte TO, Kessler S, Schlie J, et al. (2010) Bone mineralization defects and vitamin $D$ deficiency: Histomorphometric analysis of iliac crest bone biopsies and circulating 25-hydroxyvitamin $D$ in 675 ? patients Journal of Bone and Mineral Research 25: 305-312. 
26. Hyppönen E, Power C (2007) Hypovitaminosis D in British adults at age $45 \mathrm{y}$ : nationwide cohort study of dietary and lifestyle predictors. Am J Clin Nutr 85: 860-868
27. Raby BA, Lazarus R, Silverman EK, Lake S, Lange C, et al. (2004) Association of vitamin $D$ receptor gene polymorphisms with childhood and adult asthma. Am J Respir Crit Care Med 170: 1057-1065. 